\title{
Prevalence of hepatitis E virus antibodies in individuals exposed to swine in Mato Grosso, Brazil
}

\author{
Sabrina Monteiro Tosoncin da Silva1, Jacqueline Mendes de Oliveira², Cláudia Lamarca Vitral2, ${ }^{2}$, \\ Karina de Almeida Vieira ${ }^{4}$, Marcelo Alves Pinto², Francisco José Dutra Souto ${ }^{4}+$
}

1'Laboratório Central de Saúde Pública de Mato Grosso, Cuiabá, MT, Brasil ²Departamento de Virologia, Instituto Oswaldo Cruz-Fiocruz, Rio de Janeiro, RJ, Brasil ${ }^{3}$ Departamento de Microbiologia e Parasitologia, Instituto Biomédico, Universidade Federal Fluminense, Niterói,

RJ, Brasil ${ }^{4}$ Faculdade de Medicina, Universidade Federal do Mato Grosso, Av. Fernando Correa 2367, 78060-900 Cuiabá, MT, Brasil

This study was conducted to estimate the prevalence of hepatitis E antibodies (anti-HEV) among individuals exposed to swine in the rural areas of the state of Mato Grosso (MT) in Brazil. The study included 310 participants who had an average age of 39 years. Fifty-one per cent of the participants were female and 26 (8.4\%) were antiHEV-positive. Concomitantly, we studied 101 blood donors from the urban area of the state capital who had never lived in a rural area or handled swine. Four per cent (4\%) of these individuals were anti-HEV-positive $(p=0.206)$. When we compared the anti-HEV-positive participants who had been exposed to swine with the anti-HEV-negative participants, we noticed associations between the presence of anti-HEV and increased age, a history of blood transfusions and contact with other farm animals. However, after a multivariate analysis was performed, this association was not confirmed. Finally, the ratio of anti-HEV-positive individuals who had been exposed to swine in rural MT was similar to that found in previous studies in Brazil. This prevalence did not characterise this type of exposure as a risk factor for HEV infection in this region.

Key words: hepatitis E virus - swine - domestic animals - farm workers - zoonotic transmission - occupational transmission

Infections with hepatitis E virus (HEV) can appear as either sporadic cases or an epidemic form and both of these types of infection are related to poor hygiene and unsanitary conditions in regions where this virus is endemic, which mainly include countries in Asia and Africa (Dalton et al. 2008). In industrialised countries, sporadic cases have been reported in individuals with a history of travel to regions where the virus is endemic. However, reports of autochthonous cases in non endemic countries have increased in recent years (Clemente-Casares et al. 2003, Galiana et al. 2010, Pavio \& Mansuy 2010).

In 1997, HEV was isolated from swine at commercial farms in the USA. These HEV isolates were very similar to those found in humans in the same region (Meng et al. 1997). Today, it is widely known that strains of genotype 3 HEV circulate extensively in swine across all continents and anti-HEV antibodies have also been found in other species of domestic and wild mammals (Arankalle et al. 2001, Vitral et al. 2005). HEV isolates from swine in several regions worldwide have demonstrated a significant degree of homology to the human strains of HEV present in the same regions (Huang et al. 2002, Takahashi et al. 2004, Okamoto 2007, dos Santos et al. 2010). These findings led to the hypothesis that autochthonous cases reported in non endemic countries may have been the result of zoonotic transmission due to ani-

+ Corresponding author: fsouto@terra.com.br

Received 11 June 2011

Accepted 11 January 2012 mal handling or the consumption of raw or undercooked meat (Purcell \& Emerson 2001, Tei et al. 2003, Dalton et al. 2008). Therefore, individuals who are occasionally exposed to animals may have an increased risk of HEV zoonotic transmission (Meng 2003, Vitral et al. 2005).

In the state of Mato Grosso (MT), which is one of the top regions for swine production in Brazil, there is evidence for a high level of circulation of genotype $3 \mathrm{HEV}$ among swine (Guimarães et al. 2005, dos Santos et al. 2009). However, it has not been investigated whether individuals who came into contact with these animals would possess an increased risk for this type of infection.

\section{SUBJECTS, MATERIALS AND METHODS}

This study aimed to estimate the prevalence of antiHEV antibodies among residents of rural MT who handled swine and their carcasses. To study these farms, the research team received assistance from the state inspection agency [Instituto de Defesa Agropecuária de Mato Grosso (INDEA)], an institution that catalogues and systematically inspects rural properties. The municipalities and farms were visited according to pre-specified plans made by the INDEA-MT for the relevant time period. Two other municipalities were not visited due to concerns about cases of pandemic swine influenza during the field stage of the research.

The sample size was calculated on the basis of a previously reported anti-HEV seroprevalence of $6.3 \%$ among swine handlers in Rio de Janeiro (Vitral et al. 2005). The variance was estimated to be $+/-3 \%$ of this prevalence value with a confidence level of $95 \%$. Finally, an additional $20 \%$ was added to account for missing data. According to these parameters, this study aimed to include 282 participants. 


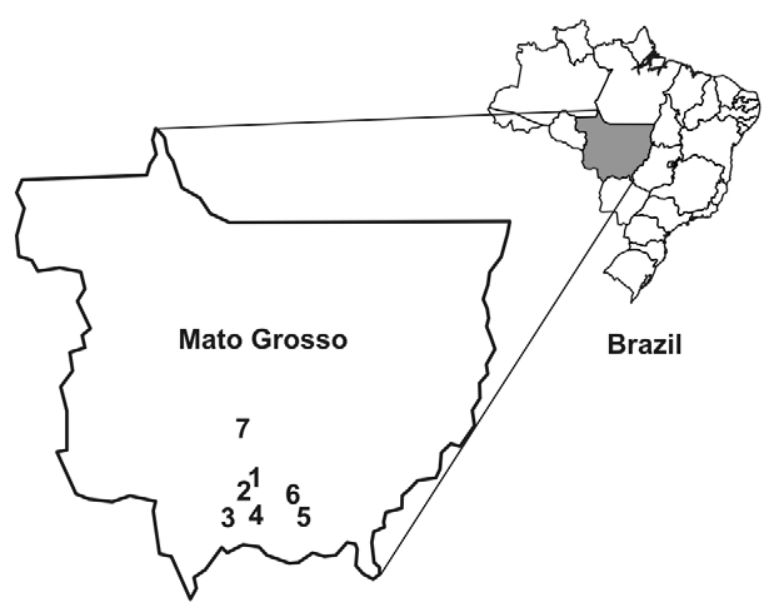

Map of the state of Mato Grosso showing the seven municipalities included in the study (percentages represent sample from each one). 1: Cuiabá (6\%); 2: Várzea Grande (26\%); 3: Nossa Senhora do Livramento (23\%): 4: Santo Antonio de Leverger (4\%); 5: Rondonópolis (25\%); 6: Campo Verde (11\%); 7: Diamantino (5\%).

All self-declared healthy inhabitants and workers older than 10 years of age were invited to participate in the study and received an explanation of the goals of the study. Data regarding demographic characteristics, access to potable water, wastewater disposal and the types of exposure to swine and other farm animals were obtained through interviews with the participants. Blood samples were taken from the antecubital vein for serologic testing. The results were stored and analysed using the EpiData Entry software program, version 3.1 (The EpiData Association, Odense, Denmark, 2008).

The anti-HEV IgG analysis was performed using an immunoenzymatic assay provided by MP Diagnostics (MPD HEV ELISA, MP Biomedicals Asia Pacific Pte Ltd, Singapore). As the sensitivity, specificity and accuracy profiles of the kits used to detect the presence of anti-HEV IgG vary significantly and because the kit that was used in this study had never been used in MT, the blood samples of donors from the state capital were tested. Donors who had lived in rural areas or who had been in contact with swine farms were discarded.

Data were analysed using the EpiData Analysis program (2009). The exposure odds ratios for the presence of anti-HEV IgG and the $95 \%$ confidence intervals (CI) were calculated. A p value less than 0.05 was considered statistically significant. A logistic regression model was constructed using Stata 8.2 (StataCorp, College Station, Texas, USA, 2005) for the variables that demonstrated significant associations in the univariate analysis.

The protocol for this study was evaluated by the Research Ethical Committee of the Júlio Müller University Hospital of Federal University of Mato Grosso (protocol 344/CAP-HUJM/2009) and was approved on 26 May 2009. All individuals who agreed to participate in the study signed informed consent forms stating that they were participating out of free will.

\section{RESULTS}

For this study, 54 rural properties where swine were raised or slaughtered were visited between July 2009January 2010 throughout seven municipalities of the centre southern region of MT (Figure). The INDEA could not determine the number of properties within this region. Thus, during the field work, the researchers examined all of the properties that the INDEA team visited and refusals to participate were uncommon.

The study included 310 participants between the ages of 11-98 years who had an average age of $39.8 \pm$ 18.3 years. The majority of the participants were female (51\%). Of the 310 subjects, $210(67.7 \%)$ stated that they drank non potable water and none of the rural properties that were visited were connected to the public sewage system.

The majority of the participants (59.4\%) lived on subsistence family farms and 65 (21\%) lived on commercial farms that were certified by the INDEA. The remainder of the participants (19.7\%) worked in slaughterhouses. One hundred and thirty-six (43.9\%) participants had worked with swine for over 10 years. One hundred and seventeen $(37.7 \%)$ participants had occupational contact with other animals in addition to swine. One hundred and seventy $(54.8 \%)$ participants slaughtered swine and $235(75.8 \%)$ handled the carcasses of these animals.

Twenty-six of the 310 participants $(8.4 \%$; CI $95 \%$ $=5.6-12.2)$ were anti-HEV-positive. Individuals who were anti-HEV-positive $(n=26)$ did not differ from anti-HEV-negative $(n=284)$ participants in terms of age, gender or education level. However, we noticed that the anti-HEV-positive prevalence levels tended to increase with age (Table I).

The serum samples of 110 blood donors were tested and four $(4 \%$; CI $95 \%=1.3-10.4 \%)$ of the serum samples were positive for anti-HEV IgG. There was no statistically significant difference between this percentage and that found for participants from rural areas $(\mathrm{p}=0.206)$.

Moreover, sanitary conditions, such as access to potable water and wastewater disposal, were not associated with the presence of anti-HEV antibodies. Additionally, there were no associations between the type of property the participants worked in or whether the individuals performed swine slaughtering or carcass handling and the presence of anti-HEV IgG. The presence of anti-HEV antibodies was more frequent among individuals who reported that they had raised other species of animals in addition to swine $(\mathrm{p}=0.047)$. Anti-HEV antibodies were detected in five $(21.7 \%)$ of the individuals who had reported having received a blood transfusion and in $21(7.3 \%)$ of the individuals who had not received a transfusion $(\mathrm{p}=0.016)$.

To monitor the associations between the presence of anti-HEV antibodies and a history of having received a blood transfusion or exposure to other farm animals, a logistic regression model was constructed using the Stata 8.2 software program (2006). This analysis was controlled by gender and age and did not confirm any of these potential associations (Table II). 
TABLE I

Analysis of the association of demographic factors and presence of anti-hepatitis E virus (HEV) $\operatorname{IgG}$ among the 310 participants exposed to swine, state of Mato Grosso, 2009-2010

\begin{tabular}{|c|c|c|c|c|}
\hline Characteristics & $\begin{array}{l}\text { Anti-HEV+ } \\
\text { n }(\%)\end{array}$ & $\begin{array}{c}\text { Anti-HEV- } \\
\text { n (\%) }\end{array}$ & $\begin{array}{c}\text { OR } \\
(95 \% \mathrm{CI})\end{array}$ & $\mathrm{p}$ \\
\hline Total & $26(8.4)$ & $284(91.6)$ & - & - \\
\hline \multicolumn{5}{|l|}{ Gender } \\
\hline Female & $17(10.8)$ & $141(89.2)$ & 1.0 & - \\
\hline Male & $9(5.9)$ & $143(94.1)$ & $0.5(0.2-1.3)$ & 0.124 \\
\hline \multicolumn{5}{|l|}{ Age } \\
\hline $10-30$ & $7(5.9)$ & $111(94.1)$ & 1.0 & - \\
\hline $30-50$ & $7(7.3)$ & $89(92.7)$ & $1.2(0.4-3.7)$ & - \\
\hline$\geq 50$ years old & $12(12.5)$ & $84(87.5)$ & $2.2(0.8-6.0)$ & $0.203^{a}$ \\
\hline Median (25-75) & $47.5(27-59)$ & $36.5(23-53)$ & - & $0.052^{b}$ \\
\hline \multicolumn{5}{|l|}{ Blood transfusion } \\
\hline No & $21(7.3)$ & $266(92.7)$ & 1.0 & - \\
\hline Yes & $5(21.7)$ & $18(78.3)$ & $3.5(1.2-10.4)$ & 0.016 \\
\hline \multicolumn{5}{|l|}{ Type of property } \\
\hline Artisanal farm & $15(8.2)$ & $169(91.8)$ & 1,0 & - \\
\hline Commercial farm & $6(9.2)$ & $59(90.8)$ & $0.9(0.3-2.3)$ & 0.787 \\
\hline Slaughterhouse & $5(8.2)$ & $56(91.8)$ & $0.9(0.3-2.8)$ & 0.991 \\
\hline \multicolumn{5}{|c|}{ Time of exposure to swine (years) } \\
\hline$\leq 1$ & $1(3.1)$ & $31(96.9)$ & 1.0 & - \\
\hline $1-5$ & $7(7.6)$ & $85(92.4)$ & $2.5(0.3-57.4)$ & - \\
\hline $5-10$ & $5(10)$ & $45(90)$ & $3.4(0.3-81.8)$ & - \\
\hline$\geq 10$ & $13(9.6)$ & $123(90.4)$ & $3.3(0.4-69.6)$ & $0.650^{a}$ \\
\hline \multicolumn{5}{|c|}{ Presence of other farm animals } \\
\hline No & $11(5.7)$ & $182(94.3)$ & 1.0 & - \\
\hline Yes & $15(12.8)$ & $102(87.2)$ & $2.4(1.0-5.9)$ & 0.047 \\
\hline \multicolumn{5}{|l|}{ Swine slaughtering } \\
\hline No & $10(7.1)$ & $130(92.9)$ & 1.0 & - \\
\hline Yes & $16(9.4)$ & $154(90.6)$ & $1.3(0.5-3.3)$ & 0.473 \\
\hline \multicolumn{5}{|l|}{ Carcass handling } \\
\hline No & $3(4)$ & $72(96)$ & 1.0 & - \\
\hline Yes & $23(9.8)$ & $212(90.2)$ & $2.6(0.7-11.4)$ & 0.115 \\
\hline
\end{tabular}

$a$ : $\mathrm{p}$ value of chi-squared for trend; $b$ : $\mathrm{p}$ value from the comparison of the medians of positive and negative anti-HEV groups using Mann-Whitney test; CI: confidence interval; OR: odds ratio.

\section{TABLE II}

Multivariate analysis to adjust variables initially associated with anti-hepatitis E virus (HEV) among farm workers in rural Mato Grosso, 2009-2010

\begin{tabular}{lcccc}
\hline Variables & \multicolumn{5}{c}{ HEV+ } \\
\cline { 2 - 5 } & $\begin{array}{c}\text { Gross OR } \\
(95 \% \mathrm{CI})\end{array}$ & $\mathrm{p}$ & $\begin{array}{c}\text { Adjusted OR } \\
(95 \% \mathrm{CI})\end{array}$ & $\mathrm{p}$ \\
\cline { 2 - 5 } & - & $0.052^{b}$ & $1.0(0.99-1.03)$ & 0.189 \\
Age $^{a}$ & $0.5(0.2-1.3)$ & 0.183 & $0.6(0.25-1.42)$ & 0.246 \\
Male $_{\text {Transfusion }}$ & $3.5(1.2-10.4)$ & 0.016 & $1.0(0.99-1.03)$ & 0.076 \\
Other animal & $2.4(1.0-5.9)$ & 0.047 & $1.9(0.82-4.45)$ & 0.136
\end{tabular}

$a$ : age analyzed as continuous variable (per year); $b: \mathrm{p}$ value from the comparison of the medians of the positive and negative anti-HEV groups using the Mann-Whitney test; CI: confidence interval; OR: odds ratio.

\section{DISCUSSION}

Studies have been conducted on workers who handle swine in other countries that are considered to be non endemic and these studies found a higher prevalence of anti-HEV antibodies than that found in the current study (Drobeniuc et al. 2001, Li et al. 2006, Galiana et al. 2010). This prevalence is typically related to age and other risk factors, such as occupational exposure to swine, history of travelling to other endemic countries and drinking non potable water or unpasteurised milk. The prevalence of anti-HEV antibodies among individuals in this study was $8.4 \%$, which is higher than that found in a previous study by Vitral et al. (2005) that was performed in Brazil and evaluated the same type of workers. However, the prevalence found in the current study was not significantly greater than the prevalence found among blood donors from the closest urban centre. This lack of a significant difference may be attributed to the small number of donors (type II error). 
Another limiting factor is the variability in the sensitivity and specificity of the anti-HEV serum tests. The commercially available anti-HEV ELISA tests only use antigens derived from genotypes 1 and 2 of HEV (Myint et al. 2006) and these tests may underestimate the HEV seroprevalence in non endemic regions where genotype 3 of HEV is the most prevalent. However, the frequency of anti-HEV antibodies found in the current study was similar or greater than that demonstrated for blood donors or the general population in Brazil (Souto \& Fontes 1998, Trinta et al. 2001, Assis et al. 2002, dos Santos et al. 2002, Bortoliero et al. 2006). Consequently, reduced sensitivity did not occur in the current study.

In conclusion, this study found a slightly higher prevalence of anti-HEV antibodies than that indicated in previous studies from Brazil. Contact with swine or swine carcasses was not associated with an increase in HEV exposure among subjects living in rural MT, a region with intense circulation of this agent among these types of animals. In addition, none of the variables investigated demonstrated any association with the presence of anti-HEV antibodies, which reduced the likelihood that this occupation constitutes a risk factor for contracting HEV. However, additional studies are necessary to investigate whether this occupation results in a greater risk of acquiring HEV infection in this region.

\section{REFERENCES}

Arankalle VA, Joshi MV, Kulkarni AM, Gandhe SS, Chobe LP, Rautmare SS, Mishra AC, Padbidri VS 2001. Prevalence of antihepatitis E virus antibodies in different Indian animal species. $J$ Viral Hepat 8: 223-227.

Assis SB, Souto FJ, Fontes CJ, Gaspar AM 2002. Prevalence of hepatitis A and E virus infection in school children of an Amazonian municipality in Mato Grosso state. Rev Soc Bras Med Trop 35: 155-158.

Bortoliero AL, Bonametti AM, Morimoto HK, Matsuo T, Reiche EM 2006. Seroprevalence for hepatitis E virus (HEV) infection among volunteer blood donors of the Regional Blood Bank of Londrina, state of Paraná, Brazil. Rev Inst Med Trop Sao Paulo 48: 87-92.

Clemente-Casares P, Pina S, Buti M, Jardi R, Martin M, Bofill-Mas S, Girones S 2003. Hepatitis E virus epidemiology in industrialized countries. Emerg Infect Dis 9: 448-454.

Dalton HR, Bendall R, Ijaz S, Banks M 2008. Hepatitis E: an emerging infection in developed countries. Lancet Infect Dis 89: 698-709.

dos Santos DCM, Souto FJD, Santos DRL, Vitral CL, Gaspar AMC 2002. Seroepidemiological markers of enterically transmitted viral hepatitis $\mathrm{A}$ and $\mathrm{E}$ in individuals living in a community located in north area of Rio de Janeiro, RJ, Brazil. Mem Inst Oswaldo Cruz 97: 637-640.

dos Santos DR, Lewis-Ximenez LL, da Silva MF, de Sousa PS, Gaspar AM, Pinto MA 2010. First report of a human autochthonous hepatitis E virus infection in Brazil. J Clin Virol 47: 276-279.

dos Santos DR, Vitral CL, de Paula VS, Marchevsky RS, Lopes JF, Gaspar AM, Saddi TM, Júnior NC, Guimarães F de R, Júnior JG, Ximenes LL, Souto FJ, Pinto MA 2009. Serological and molecular evidence of hepatitis E virus in swine in Brazil. Vet J 182: 474-480.
Drobeniuc J, Favorov MO, Shapiro CN, Bell BP, Mast EE, Dadu A, Culver D, Iarovoi P, Robertson BH, Margolis HS 2001. Hepatitis $\mathrm{E}$ virus antibody prevalence among persons who work with swine. J Infect Dis 184: 1594-1597.

Galiana C, Fernández-Barredo S, Pérez-Gracia MT 2010. Prevalencia del virus de la hepatitis E (VHE) y factores de riesgo en trabajadores de explotaciones porcinas y donantes voluntarios. Enferm Infecc Microbiol Clin 28: 602-607.

Guimarães RF, Saddi T, Pinto M, Vitral CL, Souto FJ 2005. Hepatitis E virus antibodies in swine herds of Mato Grosso state, central Brazil. Braz J Microbiol 36: 223-226.

Huang FF, Haqshenas G, Shivaprasad HL, Guemette DK, Woolcock PR, Larsen CT, Pierson SW, Elvinger F, Toth TE, Meng XJ 2002. Heterogeneity and seroprevalence of a newly identified avian hepatitis E virus from chickens in the United States. J Clin Microbiol 40: 4197-202.

Li RC, Ge SX, Li YP, Zheng YJ, Nong Y, Guo QS, Zhang J, Nq MH, Xia NS 2006. Seroprevalence of hepatitis E virus infection, rural southern people's Republic of China. Emerg Infec Dis 12: 1682-1688.

Meng XJ 2003. Swine hepatitis E virus: cross-species infection and risk in xenotransplantation. Curr Top Microbiol Immunol 278: 185-216.

Meng XJ, Purcell RH, Halbur PG, Lehman JR, Webb DM, Tsareva TS, Haynes JS, Thacker BJ, Emerson SU 1997. A novel virus in swine is closely related to the human hepatitis E virus. Proc Natl Acad Sci USA 94: 9860-9865.

Myint KS, Endy TP, Gibbons RV, Laras K, Mammen MP Jr, Sedyaningsih ER, Seriwatana J, Glass JS, Narupiti S, Corwin AL 2006. Evaluation of diagnostic assay for hepatitis E virus in outbreak setting. J Clin Microbiol 4: 1581-1583.

Okamoto H 2007. Genetic variability and evolution of hepatitis E virus. Virus Res 127: 216-228.

Pavio N, Mansuy JM 2010. Hepatitis E in high-income countries. Curr Opin Infect Dis 23: 521-527.

Purcell RH, Emerson SU 2001. Animal models of hepatitis A and E. ILAR J 42: 161-177.

Souto FJ, Fontes CJ 1998. Prevalence of IgG-class antibodies against hepatitis $\mathrm{E}$ virus in a community of southern Amazon: a randomized survey. Ann Trop Med Parasitol 92: 623-625.

Takahashi K, Kitajima N, Abe N, Mishiro S 2004. Complete or nearcomplete nucleotide sequences of hepatitis $\mathrm{E}$ virus genome recovered from a wild boar, a deer and four patients who ate the deer. Virology 330: 501-505.

Tei S, Kitajima N, Takajashi K, Mishiro S 2003. Zoonotic transmission of hepatitis $\mathrm{E}$ virus from deer to human beings. Lancet 362 : 371-373.

Trinta KS, Liberto MIM, de Paula VS, Yoshida CFT, Gaspar AMC 2001. Hepatitis E virus infection in selected Brazilian populations. Mem Inst Oswaldo Cruz 96: 25-29.

Vitral CL, Pinto MA, Lewis-Ximenez LLL, Khudyakov YE, dos Santos DR, Gaspar AMC 2005. Serological evidence of hepatitis E virus infection in different animal species from the Southeast of Brazil. Mem Inst Oswaldo Cruz 100: 117-122. 